・论坛・

\title{
论《濒危野生动植物种国际贸易公约》 物种概念的内涵和外延
}

\author{
蒋志刚* \\ (中国科学院动物研究所, 中华人民共和国濒危物种科学委员会, 北京 100101)
}

\section{On the connotation and extension of species concept used by the Conven- tion on International Trade in Endangered Species of Wild Fauna and Flora (CITES)}

\author{
Zhigang Jiang* \\ Institute of Zoology, Chinese Academy of Sciences; Endangered Species Scientific Commission, P.R.C., Beijing 100101
}

2016年9月23日至10月3日, 在南非约翰内斯堡 举行的《濒危野生动植物种国际贸易公约》第17届 缔约方大会(The $17^{\text {th }}$ Conference of the Parties to the Convention on International Trade in Endangered Species of Wild Fauna and Flora, CITES CoP 17)上, 讨论了由各缔约方提交的近120项有关濒危野生动 植物贸易管制、立法、执法等的政策性议题，审议 了62项附录修订提案, 其中51项获得通过。2016年 12月16日，公约秘书处发布2016年第68号电子公 告, 公布了第17届缔约方大会后更新的《濒危野生 动植物种国际贸易公约》附录I、II和III。该附录自 2017年1月2日起生效(cites.org)。公约附录中文翻译 版本已于2017年1月由中华人民共和国濒危物种进 出口管理办公室和中华人民共和国濒危物种科学 委员会共同编印发布(cites.org.cn)。

《濒危野生动植物种国际贸易公约》有183个 缔约方, 其宗旨是确保野生动植物国际贸易不危害 野生动植物的野外生存, 对其附录中的濒危物种国 际贸易实施管理。禁止附录I物种的国际商业贸易, 仅在贸易对物种野外种群“非致危”的前提下允许附 录II物种实行许可证管理的国际商业贸易(蒋志刚, 2011)。列入附录I和附录II的物种由缔约方大会通
过，列入附录III的物种则由 1 个或多个缔约方提出 并执行管理。每届缔约方大会都要修订公约的附 录。到目前为止, 已有 5,600 多种动物和 30,000 多种 植物被列入公约附录，使得世界范围内60-65\%的 野生动植物种国际贸易得到了有效控制。《濒危野 生动植物种国际贸易公约》已成为控制野生动植物 及其产品国际贸易、保护生物多样性的一项有效 的、可操作性强的国际条约(Wijnstekers, 2009)。

《濒危野生动植物种国际贸易公约》是一项以物 种为基础、旨在保护珍稀濒危野生动植物物种的国 际公约, 因此, “物种”概念是其核心。目前关于物种 概念的争议颇多(孔宏智, 2016)，对一个物种的分类 地位常常不能达成一致。那么, 以物种为核心的《濒 危野生动植物种国际贸易公约》怎么处理这一难 题? 公约附录文本规定：“本附录所列的物种是指： (a)名称所示的物种或(b)一个高阶分类单元所包括 的全部物种或其被特别指定的一部分”(cites.org), 即公约的“物种”概念内涵是生物学家认定的“物 种”，但其外延则扩大到“物种”以上的分类阶元，如 “属”、“科”，甚至可能是“目”，以及一个“属”、一个 “科”或是一个“目”的部分物种，甚至还可能指一个 “种”的亚种和种群(图1)。

收稿日期: 2016-12-29; 接受日期: 2016-12-30

基金项目: 国家科技部基础性专项(2013FY110300)、国家自然科学基金(31372175)和国家重点研发计划课题(2016YFC0503303)

* 通讯作者 Author for correspondence. E-mail: jiangzg@ioz.ac.cn 


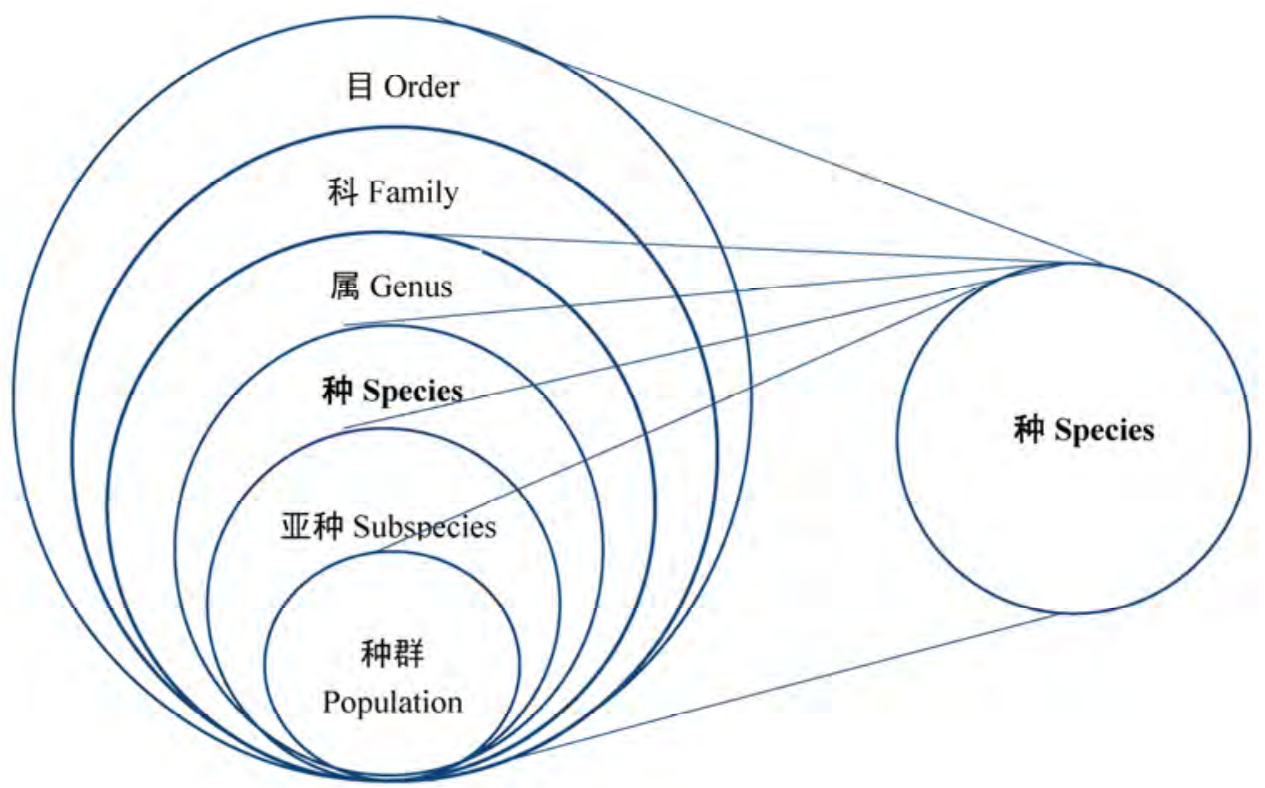

图1《濒危野生动植物种国际贸易公约》物种概念的内涵和外延。其“物种”概念内涵是生物学家认定的“物种”, 但其外延则 扩大到“物种”以上的分类单元，如“属”、“科”，甚至可能是“目”，以及一个“属”、一个“科”或是一个“目”的部分物种，还甚至 可能指一个“种”的亚种和种群。

Fig. 1 Connotation and extension of the species concept used by the Convention on International Trade in Endangered Species of Wild Fauna and Flora (CITES). The connotation of species concept used by CITES is the connotation by name of the species recognized by biologists, whereas the extension of the concept is extended to as being all of the species included in a higher taxon, such as "genus”, “family” or even “order”, or designated part thereof. Species of CITES may also refer to subspecies or population.

在目级阶元上，灵长目 ${ }^{(1)}$ 、鲸目、隼形目、鳄目、 鲟形目和角珊瑚目的所有种, 分别被列入附录 I和 附录II。树鼠目的所有种则全被列入附录II。在科级 与亚科级阶元上, 猫科 (Felidae) 、西貒科 (Tayassuidae)、熊科(Ursidae)、蜂鸟科(Trochilidae)、 鹤科 (Gruidae) 、铇 科 (Otididae) 、极乐鸟科 (Paradisaeidae)、美洲闪鳞蛇科(Loxocemidae)、蟒科 (Pythonidae)、林蚰科 (Tropidophiidae)、陆龟科 (Testudinidae)、砗䃈科 (Tridacnidae)、仙人掌科 (Cactaceae) 、苏铁科 (Cycadaceae) 、龙树科 (Didiereaceae)、兰科(Orchidaceae)的所有种, 以及水 獭亚科(Lutrinae)的所有种, 分别被列入附录 I和附 录 II; 红鹳科(Phoenicopteridae)所有种均被列入附 录II。在属级阶元上, 膺属(Moschus spp.)、毛皮海 狮属(Arctocephalus spp.)、原针鼠属(Zaglossus spp.)、 穿山甲属(Manis spp.)、皱盔犀鸟属(Aceros spp.)、凤

(1) 本文动植物分类体系和中文名均依据由中华人民共和国濒危物种进 出口管理办公室和中华人民共和国濒危物种科学委员会共同编印发布 的公约附录中文翻译版本一 《濒危野生动植物种国际贸易公约》附录 I、附录 II 和附录 III (cites.org.cn)。
头犀鸟属(Anorrhinus spp.)、斑犀鸟属(Anthracoceros spp.)、白冠犀鸟属(Berenicornis spp.)、犀鸟属 (Buceros spp.)、斑嘴犀鸟属(Penelopides spp.)、拟皱 盔犀鸟属(Rhyticeros spp.)、大鲵属(Andrias spp.)、 棘尾蚚属(Saara spp.)、刺尾蚚属(Uromastyx spp.)、 塞舌尔避役属 (Archaius spp.) 、侏儒避役属 (Bradypodion spp.)、变色龙属(Brookesia spp.)、绳蜥 属(Cordylus spp.)、拉马绳蚚属(Namazonurus spp.)、 拟绳蜥属 (Hemicordylus spp.) 、卡卢绳蚚属 (Karusaurus spp.)、毒蜥属(Heloderma spp.)、巨蚚属 (Varanus spp.)、箭毒蛙属(Dendrobates spp.)、前口 蝠鲼属(Manta spp.)、蝠鲼属(Mobula spp.)、海马属 (Hippocampus spp.)、雪花莲属(Galanthus spp.)、棒 锤树属(Pachypodium spp.)、酒瓶兰属(Beaucarnea spp.)、杪椤属(Cyathea spp.)、芦荟属(Aloe spp.)、仙 客来属(Cyclamen spp.)、瓶子草属(Sarracenia spp.)、 沉香属(Aquilaria spp.)、棱柱木属(Gonystylus spp.)、 拟沉香属(Gyrinops spp.)的所有种, 分别被列入附 录I和附录II。因此, 公约附录的动植物以物种为主, 并可能收录一个属、一个科甚至一个目的所有种。 
公众可能很难分辨特定生物种类，如不同的海 马种类。于是, 除被列入附录 I的物种外, 海马属所 有种均被列入了附录II, 其国际贸易受到严格的监 管。在第17届缔约方大会上所有的穿山甲均被列入 附录I, 禁止贸易。这样, 避免了分辨特定物种的困 难, 方便海关和市场执法人员对海马、穿山甲进出 口和市场的管理。同时也回避了物种划分的困难, 避开了分类学家的争议。

同一物种的不同亚种、种群的商业利用和收藏 价值不同，因而受到国际贸易的威胁程度不同。公 约还将一些种的亚种列入其附录, 如马鹿巴克特利 亚亚种(Cervus elaphus bactrianus)被列入附录I; 黄 披肩吸蜜鸟卡西迪亚种(Lichenostomus melanops cassidix)、大貂羚安哥拉亚种 (Hippotragus niger variani)、美洲小沱指名亚种(Pterocnemia pennata pennata)、盘羊西藏亚种(Ovis ammon hodgsonii)、 盘羊西哈萨克斯坦亚种(O. a. nigrimontana)、东方盘 羊塞浦路斯亚种(O. orientalis ophion)和维氏盘羊指 名亚种(O. vignei vignei)都被列入了附录 I。公约甚至 将一些物种的种群列入其附录, 如不丹、印度、尼 泊尔和巴基斯坦的狼(Canis lupus)种群被列入附录 $\mathrm{I}$; 其他狼种群则被列入附录II。俄罗斯联邦的人参 (Panax ginseng)种群被列入附录II。对不同亚种、不 同种群实施不同的管理措施, 既保护了濒危野生动 植物种群, 控制了其国际贸易, 又达到了可持续利 用生物资源的目的。

生物多样性事业需要科学、可操作的物种概念 (洪德元, 2016)。《濒危野生动植物种国际贸易公约》 指定了植物、无脊椎动物、鱼类、两栖类、爬行类、 鸟类和哺乳类物种命名参考著作。第17届缔约方大 会通过了标准命名法决议修正案Conf.12.11 (Rev. CoP17 (cites.org)。然而, 由于物种本身的特征(张德 兴, 2016; 谢平, 2016), 加之分子生物学手段、大数 据的应用, 科学考察手段的更新, 新物种不断被发 现, 分类学家们在不断厘定物种分类地位(刘建全, 2016), 提出新的生物分类系统, 但公约末及时更新 其参考著作目录, 因而也没有更新其依据的分类系 统。例如, 关于哺乳动物的分类系统, 《濒危野生动 植物种国际贸易公约》仍参考 Wilson和 Reeder (2005)的著作, 自Handbook of the Mammals of the World 第1卷(Wilson \& Mittermeier, 2009)出版以来,
Wilson和Reeder (2005)的哺乳动物分类系统已经陆 续被修正。尽管未能应用修订的分类系统, 《濒危野 生动植物种国际贸易公约》的实践仍然提供了一种 解决物种难题的模式。物种与分类系统是不同学派 对生命世界的认识, 不同学派有不同观点; 而生命 世界是客观存在, 是唯一的。

\section{参考文献}

Hong DY (2016) Biodiversity pursuits need a scientific and operative species concept. Biodiversity Science, 24, 979999. (in Chinese with English abstract) [洪德元 (2016) 生 物多样性事业需要科学、可操作的物种概念. 生物多样 性, 24, 979-999.]

Jiang ZG (2011) Non-detrimental findings should be enhanced for the management of international trade in endangered species of wild fauna and flora. Biodiversity Science, 19, 495-496. (in Chinese) [蒋志刚 (2011) 濒危野生动植物种 国际贸易管理亟待加强贸易物种的非致危性判断. 生物 多样性, 19, 495-496.]

Kong HZ (2016) Biodiversity undertakings call for extensive discussion on species concept and the criteria for species delimitation. Biodiversity Science, 24, 977-978. (in Chinese) [孔宏智 (2016) 生物多样性事业呼唤对物种概念和物种 划分标准的深度讨论. 生物多样性, 24, 977-978.]

Liu JQ (2016) “The integrative species concept” and "species on the speciation way”. Biodiversity Science, 24, 10041008. (in Chinese with English abstract) [刘建全 (2016) “整合物种概念”和 “分化路上的物种”. 生物多样性, 24 , 1004-1008.]

Wijnstekers W (2009) The Evolution of CITES: A Reference to the Convention on International Trade in Endangered Species. CITES, Lausanne, Switzerland.

Wilson DE, Mittermeier RA (2009) Handbook of the Mammals of the World, Vol. 1, Carnivores. Lynx Edicions, Barcelona.

Wilson DE, Reeder DM (2005) Mammal Species of the World. A Taxonomic and Geographic Reference, 3rd edn. John Hopkins University Press, New York.

Xie P (2016) A brief review on the historical changes in the concept of species. Biodiversity Science, 24, 1014-1019. (in Chinese with English abstract) [谢平 (2016) 浅析物种概 念的演变历史. 生物多样性, 24, 1014-1019.]

Zhang DX (2016) Why is it so difficult to reach a consensus in species concept? Biodiversity Science, 24, 1009-1013. (in Chinese with English abstract) [张德兴 (2016) 为什么在 物种概念上难以达成共识? 生物多样性, 24, 1009-1013.] 